UDC 811.163.41’342.8

https://doi.org/10.18485/ms zmsfil.2021.64.2.3

Изворни научни рад

\author{
Maja Marković \\ Dejan Sredojević
}

\title{
SPECTRAL CHARACTERISTICS \\ OF STRESSED VOWELS IN STANDARD SERBIAN: QUANTITY AND QUALITY RELATIONS*
}

\begin{abstract}
This paper presents the results of the analysis of spectral characteristics of long and short stressed vowels in Standard Serbian. This study is part of broader research into the prosodic and spectral characteristics of Serbian vowels conducted on the largest corpus of minimal pairs recorded and analyzed so far. The corpus comprised 1120 minimal pairs of words with target vowels, produced by 20 speakers (10 female and 10 male) from Novi Sad. The main objective was to describe the typical phonetic differences in the quality of long and short stressed vowels and contribute to the phonological research of Serbian with the specifically designed corpus and detailed statistical analysis. The results point to the largest distinction between the long/short vowels /e, o/, partly corroborating previous studies.

Key words: vowels, vocalic quality, vocalic quantity, Serbian language.

У раду су представљени резултати анализе спектралних карактеристика наглашених вокала под дугим и кратким акцентима у стандардном српском језику новосадског варијетета. Истраживање је спроведено на до сада највећем корпусу минималних парова речи с дугим и кратким акцентима истог квалитета, које су се налазиле у средишњем положају краћих реченица. На основу снимака 10 говорница и 10 говорника анализирано је 1120 вокала. Главни циљеви истраживања били су да се опишу типичне разлике у квалитету дугих и кратких наглашених вокала и да се допуне досадашња истраживања пажљиво бираним корпусом и детаљном статистичком анализом. Резултати показују да се највеће разлике у квалитету јављају код дугих и кратких вокала /e/ и /o/ и у том смислу делимично потврђују налазе претходних истраживања, али и показују извесне разлике у односу на њих.

Кључне речи: вокали, вокалски квалитет, вокалски квантитет, српски језик.
\end{abstract}

1. Introduction. In many languages, vowels are distinguished not only by their quality, but also in the way they employ durational characteristics, referred to as vocalic quantity. Vowel quality, which is achieved by the specific height and position of the tongue in the vocal tract, i.e., by the position of a constriction and the degree of constriction between the lingual arch and the palate, is acoustically correlated with the frequencies of the first two formants of the vowel spectrum (F1 and F2), and is perceived as the specific timbre of a sound. Quantity is associated with the phonologically distinctive vowel length in relation to another vowel or other vowels of similar quality.

The five vowels of the Standard Serbian language (/i, e, a, u, o/) all have short and long realizations which are lexically distinctive (e.g. /luk/ vs. /lu:k/), but length in Serbian has traditionally been associated with the prosodic notion of word accent,

* The study was financed by the Ministry of Education, Science and Technological Development of the Republic of Serbia under the Research grants TR32035, OI178002 and III 47040. 
rather than being regarded as a phonemic feature. ${ }^{1}$ Our main objective in this paper, without getting into the dispute about the phonological interpretation of length as either the property of a phoneme or a prosodeme, is to investigate how phonological length affects the spectral qualities of the five vowels of the Serbian language. To this end, we conducted an experiment in which we measured and statistically compared the values of the first three formants of stressed vowels in minimal pairs of words with long and short vowels in the speech of 20 speakers of Serbian of both genders. This study is part of broader research into the phonetic characteristics of the four lexical accents in Serbian. The research is based on the largest recorded corpus of minimal pairs in Serbian so far, involving the speech of 20 speakers of Standard Serbian, who all share the same regional background, and whose speech can be characterized as the Standard Serbian urban variety of Novi Sad. ${ }^{2}$

The paper is organized as follows: Section 2 gives the preliminaries on the relation between vocalic quantity and quality, on the vowel system of Serbian and the results of previous research on the effect of vocalic quantity on quality in Serbian and Croatian. ${ }^{3}$ Section 3 explains the methodology used in this particular study, describing the corpus, participants and procedure. Section 4 provides the reader with the results of the present study with the tabular and graph representations, and is followed by discussion (Section 5), where the results are interpreted and compared to those of previous studies. In the final section, we sum up the conclusions of our study and address the questions for further lines of research.

\section{PReLIMINARIES}

2.1. ON THE RELATIONSHIP OF VOCALIC QUALITY AND QUANTITY. It is well known that in various languages vocalic quantity and quality may be mutually related, in the sense that phonological length may affect the quality of vowels (starting from the seminal work by LindBLom 1963; Lehiste 1970; CATFORD 1977). ${ }^{4}$ In some languages, such as Standard English, length distinction seems to be secondary in the pairs of vowels /i: $\mathrm{I} /, \mathrm{u}: \mathrm{v} /$ and /o: $\mathrm{p} /$, the primary cue for their distinction being the spectral differences, achieved by different places of articulation between the members of each pair. Under the same circumstances, the first member will have longer duration than the second, but the difference in vowel quality is still far

${ }^{1}$ In Punišíc - SAwicka 2007: 557, Serbian is said to have 10 vowels - five short and five long ones, which differ in quantity, but not in quality ([i], [i:], [e], [e:], [a], [a:], [o], [o:], [u], [u:]).

${ }^{2}$ Novi Sad is the capital of the autonomous province of Vojvodina and the second largest city in Serbia. It is located at $45^{\circ} 46^{\circ}$ north latitude and $19^{\circ} 20^{\circ}$ east longitude. According to the 2011 census, the administrative area of Novi Sad has a population of 341,625 , while its urban area comprises 307,760 inhabitants (ЛАкчевић и др. 2014: 23). The city of Novi Sad has $20.16 \%$ university educated people people, while its urban area has 23.26\% (ЛАкчевић и др. 2013: 46-47).

${ }^{3}$ As well as Serbo-Croatian, the term used until the 1990s to denote the eastern (ekavian) variant spoken in former Yugoslavia.

${ }^{4}$ Different vocalic qualities may also result in different inherent duration of a sound, which is not phonological duration. Generally, vowels that require more time to be fully articulated (e.g., the low vowel of [a] quality) are inherently longer under the same speaking rate and in the same phonological environment compared to vowels that require less time to be articulated (e.g., high vowels of [i] or [u] quality). See Peterson - Lehiste 1960, Lehiste 1970. For Serbian, see Marković - BJelaković 2008b; МАрковић - БЈелАковић 2009б; SoviLj-Niкić 2007; SoviLJ-Nikić et al. 2018. 
more important for the perception of vowels in this language. Typically, the short vowel is produced in a more "centralized" position in the vowel space, while the long one assumes a more "peripheral" position. This is explained in terms of timing, i.e., by the fact that vocal organs may not reach the extreme target positions due to the short duration of the phonologically short vowels.

Lehiste (LeHISTE 1970) distinguishes between languages such as English, where the spectral quality may be the overriding perceptive cue, and those she terms "quantity languages", where duration alone is perceptively important. Yet, even in quantity languages, she claims to have observed at least some differences in the phonetic quality of long and short vowels. The author also points out that in a specific language, some vowels may show more preference to change quality under the influence of quantity than others, noticing that in Czech, it is the high vowels $/ \mathrm{i} /$ and $/ \mathrm{u} /$ that differ in quality in the long/short pairs, while in SerboCroatian, the most significant quality difference is associated with the two mid vowels /e/ and /o/ and the low vowel /a/ (LeHISTE 1970: 30). Since the two quantity languages differ in the preference for the affected vowels, the author concludes that this may not be a universal ('automatic', in her words, LeHISTE 1970: 32), but a language-specific phenomenon, also acknowledged by Catford (1977: 198). The minor differences in quality that occur with the other pairs of short and long vowels are only concomitant characteristics regarded as allophonic by a native speaker.

In the subsequent work on Thai (ABRAMSON - REN 1990), the authors conducted a perception experiment to test the effect of duration on the perception of the distinction between short and long vowels by incrementally changing the duration of vowels. The authors conclude that relative duration is the dominant cue to distinctive vowel length in Thai, despite the minor spectral differences in the pairs, which provide "less powerful but pertinent cues". However, it turns out that there is a "puzzling exception", and that is the pair /u: u/, which showed the reversed effect in the perception of the lengthened short vowel and the shortened long vowel compared to the other pairs tested.

In their work on Norwegian, Behne and collaborators (BEHNE et al. 1996) examined the effect of quantity on quality in three short and long vowel pairs, and showed that vowel quantity does not necessarily affect the vowel spectrum in this language. The authors conclude that Norwegian appears to use vowel duration as the primary acoustic means of distinguishing phonologically short and long vowels. Analyzing the long and short vowel pairs of Swedish (BEHNE et al. 1997), which generally exhibits the effect of quantity on quality, the authors found that for most vowel pairs analyzed it is duration that contributes to the perception of a long or short vowel, with the exception of the pair /a/ vs. /A/, where the first formant also serves as a significant perceptual cue.

On the whole, most authors who investigated the effect of vocalic quantity on quality question the existence of one single phonetic cue for distinguishing between the phonologically long and short vowels, and acknowledge that at some point in the development of a language quality may take over as the primary feature of a vowel (LeHISTE 1970; ABRAMSON - ReN 1990). This is probably the case of English and similar languages, in which spectral cues serve as primary phonological distinguishers between vowels. We hope that this research may shed 
new light on the vowel system of Standard Serbian, where some vowels (/e, o, a/) have been shown to exhibit more remarkable spectral differences in the long and short realizations.

2.2. The relation between vowel quality and quantity in Serbian. Among the 30 phonemes of Serbian, there are five vowels, all of them being pure vowels, or monophthongs, evenly placed within the vowel space - two front vowels (high /i/ and mid /e/), one central (low /a/), and two back vowels (high /u/ and mid /o/) (Subotić et al. 2012: 45-46). The two back vowels are also accompanied by substantial lip rounding or labialization. The feature of labialization may be regarded as redundant in this language, since it is only associated with back non-low vowels. According to Maddieson (MADDIESON 1984: 127), the five vowel system of this kind is the most widely attested vowel system among the languages of the world, found in as many as $21.5 \%$ of the world's languages.

Serbian being a pitch accent language, each of the five vowels may occur in syllables with long or short, falling or rising accent. ${ }^{6}$ Due to these prosodic differences, the qualities of the five vowels may vary systematically. Previous research has shown that vowel length, or quantity, may significantly affect the quality of the vowels, particularly of the two mid high vowels - the front vowel /e/ and the back /o/, and to a lesser extent, the central low vowel /a/. As for the high vowels /i/ and /u/, the results of previous studies have either been inconclusive or have shown a minimal influence of quantity. Accent type (rising or falling), on the other hand, has not been found to affect the overall vocalic quality (Ivić - LEHISTE

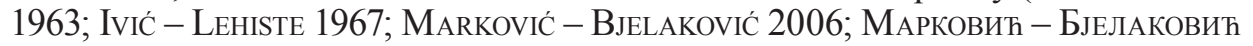
2009б; MarKović 2012).

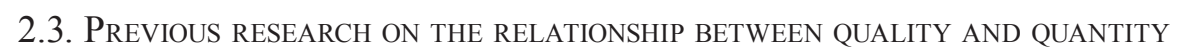
IN SERBIAN. In presenting the previous pre-experimental and experimental research on the vowels of the Serbian language, we shall limit this account only to those observations and studies which point to the correlation between vocalic quantity and quality in stressed syllables, regardless of whether they deal with the prescribed 'norm' (Standard Serbian), or describe the phenomenon within various Serbian and some Croatian dialects.

In his work on the auditory and articulatory description of the sounds of Serbian, Miletic was one of the first Serbian phoneticians to recognize the effect of quantity on different vocalic qualities. He pointed out that the five vowels in Serbian may all occur in the opposition short and long and, based on his auditory judgments and articulatory experiments, acknowledged that the difference in quantity or the position of a vowel in a word may contribute to slight differences in vocalic quality, although those differences are negligible in the pronunciation of one individual speaker (Милетић 1933: 120). Among the most remarkable allophonic differences, he singled out those between the short and long realizations of

\footnotetext{
${ }^{5}$ In addition to the five vowels, Ivić and Lehiste (IviĆ - Lehiste 1963; Ivić - LehiSTE 1967; Ивић - Лехисте 1996) subsume syllabic/r/ among vowels and analyse its prosodic and segmental characteristics.

${ }^{6}$ The urban variety of Standard Serbian spoken Novi Sad contains all four accent types mentioned, like most dialects spoken in Vojvodina. Since vowel quality and quantity are highly dialectsensitive, it is important to stress whether the dialect investigated contains these prosodic distinctions.
} 
/e/ and /o/, where the short realization is more open than the long one. He regarded the differences between the long and short allophones of /e/ and /o/ as acceptable in the standard language (Милетит 1933: 126, 133). Interestingly, while this author noted some differences between short and long realizations of $/ \mathrm{i} /$ and $/ \mathrm{u} /$, he claimed that there was no difference between short and long /a/ (Милетић 1933: 120).

In various dialectological studies, in which descriptions are based on authentic recordings and subsequent auditory analyses, various authors also point to the allophonic variations of /e/ and /o/, which are differently realized in different dialects. Among these we shall mention the studies on Šumadija-Vojvodinian dialect (Николић 1964: 307; Поповић 1968: 11-13; Ивић 1978: 149; Реметић 1985: 111-112; Шпис 1991: 554-555; Ивић и др. 1994: 154-155), on Smederevo-Vršac dialect (Ивит 2001), on Kosovo-Resavian dialect (Јовић 1968: 39-41; Пецо - МилАновић 1968: 251; РАдић 1990: 12; БукУМИРОВИЋ 2003: 75; РАдић 2010: 56-57); and on Prizren-Timok dialectal area (БЕлић 1999: 71-73).

Among Serbian and Croatian dialectologists, other observations related to our study are those on the different qualities of long and short /a/ in various dialects. Kašić (KAšıć 1995: 19-20) and Ivić (Ивић 2001: 2014) point to the different realizations of long /a/ in various dialects in the coastal region of Croatia and in Eastern-Herzegovinian dialects, where it is pronounced as a more closed, and even labialized vowel of [0] quality. This vowel may also be diphthongized in the vernaculars of Dubrovnik, resulting in [u्a] quality (БоЈАнић - ТРивунАц 2002: 12). According to Ivić (Ивић и др. 1994: 217) the retracted and labialized realization is also found in Banat vernaculars of the Vojvodinian subdialect.

The first experimental studies of vowel quality in Serbian based on the acoustic investigation into formant frequencies date back to the series of studies conducted by Lehiste and Ivić in the 1960's. The results related to the effect of quantity and quality are presented in IvIĆ - LEHISTE 1963 and IvIĆ - LEHISTE 1967. The corpus analyzed comprised 877 stressed vowels pronounced by the main informant, Ivić himself, and vowels in 116 words pronounced by 12 additional informants ( $7 \mathrm{fe}-$ male and 5 male speakers). All the informants were speakers of Standard Serbian ${ }^{7}$ and lived in Novi Sad at the time of recording, although they were originally from different regional backgrounds. Among the findings of these authors relevant for the present study, we shall mention the significant difference in formant frequencies between the long and short allophones of /e/, /o/ and /a/. These differences are manifested as higher $\mathrm{F} 1$ formants in short /e/ and /o/, indicating a more open position of the tongue, and the lower F1 in short /a/, which shows that the short allophone is produced with a slightly raised tongue position. In addition to these, F2 values also indicate centralization of tongue position of the short vowels in relation to the long ones, being lower for short/e/ and higher for short /o/. Ivić and Lehiste also found that accent type, either falling or rising, did not show any systematic effect on spectral differences in the vowels analyzed. ${ }^{8}$

\footnotetext{
${ }^{7}$ Ivić and Lehiste term the language Serbo-Croatian throughout their studies. In order to avoid potential inconvenience in comparing their findings with those of later studies, we shall refer to the language they describe as Serbian.

${ }^{8}$ However, there may be indications that short/e/ in syllables with falling accent may be more open, since F2 has higher values than in syllables with rising accent in most additional informants' pronunciation. This tendency, however, does not appear to be systematic nor do the authors offer any
} 
Among other studies which dealt with the question relevant for this paper, we shall try to sum up the findings in the following lines. Some of the results vary due to the differences in the dialectal backgrounds of the speakers involved in the studies. In most research of the correlation between quantity and quality, it was found that the short vowels /e/ and /o/ are the most prone to opening and centralization, reflected in the significant differences between the values of F1 and F2 of the respective long and short vowels.

Probably the most striking differences between the long and short realizations of the vowels /e/ and /o/ were found in Marković - BJELAKović 2006, and MARKOVIĆ 2012, where all the participants speak the typical Vojvodinian dialect characterized as the urban Novi Sad variety of Standard Serbian. Significant differences are also reported in Соколовић 1997, whose participants were of Bosnian origin, but lived in Serbia at the time of her study. Petrović and Gudurić's results (ПЕтровић - Гудурић 2010) point to the same kind of difference, again in the speech of Vojvodina. In her dissertation dealing with diverse effects of continuous speech on segments, A. Batas comes to similar conclusions, observing that the level of openness in these two vowels depends on the speakers' dialect (БАTAC 2014: 228-289, 235). Unlike these results, those of the spectral analysis of the speech of Niš (PAUNOVIĆ 2002) appear to counter the findings of other authors, but one should bear in mind that quantity distinction has also been lost in the vernacular of this area (Тома 1998: 131), which certainly may account for such a difference in the results. The studies conducted on the quantity-quality relations in Croatian point to different degrees of openness of short /e/ and /o/ in different authors. Bakran's results suggest a significant difference in F1 and F2 for short /e/ and short /o/ compared to the respective long vowels in Standard Croatian, but judging from the formant values, it is obvious that the differences in quality of short and long vowels are not as marked as in Standard Serbian (BAKRAN 1990: 5). Similar results are found in Pletikos 2003, where the author concludes that the tendencies towards centralization of some short vowels are obvious, but not significant (Pletikos 2003: 330-331). МАРКОВИЋ 2012 shows that the dispersion of vowels in Serbian is generally larger in the vowel space due to the spectral differences between long and short vowels /e/ and /o/ than in Croatian. In her doctoral dissertation about the acoustic characteristics of vowels in Standard Croatian and Standard Serbian, Bašić (BAšić 2018) analyzed the vowels of Croatian and Serbian without specifically comparing the quality of long and short vowels, but her results also indicate the largest formant dispersion in /e/ and /o/ in Serbian.

The results pertaining to the difference between long and short $/ a /$ in the studies following Ivić and Lehiste (Ivić - LeHISTE 1963; 1967) seem to be less conclusive and even not to be in line with their findings. While Sokolović concludes that /a/ in a short accented syllable is more centralized than in a long one, Paunović's results do not indicate any difference, but again care should be taken that this author's informants generally do not have the distinction in vowel quantity in their speech. Marković and Bjelaković (Marković - BJelaković 2006) find

explanation of this phenomenon. In order to investigate whether accent type contributes to the spectral qualities and come up with an adequate explanation of the potential differences, future studies would have to be designed with this specific goal in mind. 
only slight and hardly significant lowering of $\mathrm{F} 1$ in the short vowel in both genders. Batas (BATAC 2014) finds the only difference in F3, which is not related to the centralization of the short vowel. Bakran does not record any difference between the long and short realization of /a/ in Croatian either (BAKRAN 1990: 5). Other authors do not specifically highlight the difference between the quality of short and long /a/ either in Serbian or in Croatian, so that Pletikos (2003) even concludes that the results are sometimes contradictory (which can also be seen in the graph in Pletikos 2003: 331).

As for the high vowels $/ \mathrm{i} /$ and /u/, most studies generally point to minor differences, if any, between the short and long realizations. Ivić and Lehiste find no significant difference between F1 of short and long/i/, while F2 is somewhat lower, revealing a slightly centralized position. On the other hand, short /u/, according to their results, seems to be slightly more lowered and slightly fronted (also centralized), as indicated by the higher values of F1 and F2 in their informants' speech (IVIĆ - LEHISTE 1967: 63-64). Sokolović finds that the short accented $/ \mathrm{i} /$ and $/ \mathrm{u} /$ are somewhat centralized and more open than the long respective vowels. Paunović's results show slightly more open realizations of short /i/, although doubtfully significant, but F2 does not indicate any centralization in the short vowel. As for short and long $/ \mathrm{u} /$, this author does not find any significant difference between the long and short realization (PAunović 2002: 444-445). Marković and Bjelaković's results (MARKović - BJELAKOvić 2006; 2008a) also point to a slight centralization of short $/ \mathrm{i} /$ and /u/, manifested as the lower values of F2 in /i/, and higher in $/ \mathrm{u} /$. Batas also finds lower F2 values in the short realization of $/ \mathrm{i}$, but in addition to this, she mentions a surprising centralization tendency of long /u/ (БАТAC 2014: 221, 244). ${ }^{9}$ Bakran's results show slight lowering of short /i/, only seen in the higher values of F1 (BAKRAN 1990: 5), although the results of the distinction of long and short $/ \mathrm{u} /$ are inconclusive. Pletikos (2003) again finds no significant difference between the long and short realizations of $/ \mathrm{i} /$ or $/ \mathrm{u} /$.

Judging from the results of the studies presented in this section, we may conclude that the quantity and quality relationship in vowels is obviously dialectsensitive, probably changeable over time (which may explain the difference in some of the earlier and more contemporary findings), perhaps even affected by various other sociolinguistic factors, and is certainly worth investigating both across different dialects of the same language and in longitudinal studies, which may reveal potential diachronic changes in vocalic quality.

\section{ResEARCh QUESTIONS, METHODS AND TECHNIQUES}

3.1. RESEARCH QUESTIONS - RATIONALE FOR THE PRESENT STUDy. Although the spectral quality of vowels in Standard Serbian has been investigated quite extensively so far, including the vowels of the Standard Serbian urban variety of Novi Sad, none of the previous studies was done for the specific purpose of testing the effect of quantity on vocalic quality.

${ }^{9}$ This should be taken with some reserve due to the coarticulation effect in the words with $/ \mathrm{u} /$ analyzed in this study and the difficulties regarding the analysis of F1 and F2 due to their closeness and/or overlapping. 
The present study was therefore specifically designed to compare the spectral quality of long and short vowels in the same phonological environment, i.e., in minimal pairs (or near-minimal pairs) where all potential coarticulation effects, which may blur the overall results, would be avoided. To this end, we created and recorded the largest corpus of minimal pairs so far including all long : short Serbian vowels. This enabled us to carry out a more detailed and reliable analysis than in earlier studies, not simply stating the mean formant values, but also showing the statistically significant differences between the spectral characteristics of long and short vowels.

Another difference between the present and previous studies on vowels of the Standard Serbian urban variety of Novi Sad is the fact that a number of previous studies were conducted on words in isolation, whereas this one is based on words within sentences, which ensures more natural pronunciation, and as a result, may yield more reliable data.

Finally, undertaking a study of vocalic quality in contemporary language is certainly justified by the fact that vowels are the most prone to change over time, which may account for different results in the studies conducted several decades ago and those undertaken at present. In this way, we are able to capture ongoing tendencies towards more or less noticeable changes in the sound system of a language.

Our research questions, accordingly, refer not simply to the description of referential values of vowels in Novi Sad speech, but also to the effect of vocalic quantity on quality in this dialect, to the comparison of the phenomenon in this and other dialects, to the differences between the findings of previous studies and the state-of-the-art situation in this variety of Standard Serbian (or other comparable Vojvodinian dialects). Another, minor question that arose during the study, involved the potential difference in the pronunciation between the genders, which at this stage we can only note, without trying to respond to it precisely, due to our present experimental design.

3.2. SPEAKERS. The total number of participants recorded for this research is 20, 10 male and 10 female speakers aged from 19 to 53 (mean age 37, stdev 11 years). All the speakers were born and lived in Novi Sad all their life or from early childhood, and were all university graduates, university teachers or students at the time of recording..$^{10}$ Fifteen of them were teachers at the Faculty of Philosophy in Novi Sad, seven of whom were Serbian linguists, and four were students of Serbian at the Faculty of Philosophy. All the speakers use the ekavian variant of Standard Serbian. The typical pronunciation traits of some of them, in variable degrees, include the following: a) allophonic variations of vowels /e/ and /o/ are more markedly different depending on the degree of stress and quantity (cf. МАРКовић - БЈЕлАКОвић 2009б; MаRкоvić 2012) ; b) they may lack certain accentual alternations in nominal or adjectival declension and in verbal conjugation, with the limited distribution of the long postaccentual prosodeme; c) the phonetic realizations of some accents are phonetically different from those recorded in other Neo Štokavian speeches. Although none of the traits listed are exclu-

${ }^{10}$ One might argue that the length of living in an area, even from early childhood, need not be the most relevant factor for one's dialect, due to the unavoidable influence of one's parents' or relatives' dialectal traits. However, based on the auditory judgments of two trained phoneticians, all of the participants involved in this study had recognizable features of the Novi Sad accent. 
sively related to the speakers of Novi Sad origin, we believe that their joint usage and the degree in which they are exhibited make the speakers investigated recognizable among other speakers using the Standard Serbian norm.

The subjects were recorded in 2019 and 2021 in the studio at the Faculty of Philosophy in Novi Sad, with the expert help of a professional technician. The reverberation time in the studio is $0.3 \mathrm{~s}$, which guaranties the naturalness of recorded speech. The material was recorded digitally (sampling frequency: $44.1 \mathrm{kHz}$, resolution: 16 bit, software: Sound Forge 8.0, microphone: Neumann U-67).

3.3. CoRpus. The corpus analyzed consisted of the initial 65 target words containing all five vowels, and subsequently extended with additional 24 words for the purpose of this study. The words were set within short declarative or imperative sentences, where the target word occurred in the sentence medial position, preceded and followed by one stressed word (in several cases, it was preceded by two). The reasons for placing the target word in the medial position were to avoid potential vocal fry, which might happen in sentence final position, and to ensure that the target word was adequately stressed without placing contrastive focus on any other word in the sentence. The 89 words were pronounced by 20 speakers, which gives the total of 1780 vowels analyzed for their spectral quality.

Out of these, for the purpose of investigating the relation between vocalic quantity and quality, presented in this paper, we limited the analysis to 12 minimal pairs of words containing long and short falling accents (24 words in total) and 16 minimal pairs of words with long and short rising accents (32 words in total). This would amount to 1120 target vowels in total, but some of the words had to be removed from the analysis due to formant tracking errors or due to markedly nasal pronunciation in some speakers. ${ }^{11}$ Out of these, 19 pairs were disyllabic words with lexical stress on the first syllable, 7 were trisyllabic words with stress on the second syllable, and 2 trisyllabic words with stress on the first syllable.

The words selected were minimal pairs with the same segmental content, differing only in the quantity of the stressed target vowel. ${ }^{12}$ All the words were excerpted from the Dictionary of Standard Serbo-Croatian (Речник сриискохрвайскои къижевнои језика-PMC). In the strict sense, some of the words analyzed are not true minimal pairs from the standpoint of the prosodic norm. The majority of the speakers pronounced long unstressed (posttonic) vowels consistently only after short rising accents, most frequently in medial syllables, somewhat less frequently in the final closed syllables and most rarely in the final open syllables. In the speech of our subjects long postaccentual vowels do not occur following falling or long rising accents, ${ }^{13}$ after long posttonic vowels or after short unstressed vowels. ${ }^{14}$ Taking this into consideration, we selected examples such as the knjïga (book, Nsg. f.) and knjîga (book, Gpl. f.), which act as minimal pairs in the speech

${ }^{11}$ This was the case with 9 words in the whole corpus analysed. Apart from these, F3 was difficult to trace in 7 analyzed words.

${ }^{12}$ With the exception of near minimal pairs: komàdić : komádi; kvadràtić : kvadráti; vitlati : svitac; driblig : Drína; papirić : papiri; kapùtić : kapúti.

${ }^{13}$ An exception to this are examples of several speakers of our study.

${ }^{14}$ These findings are in line with previous studies of Novi Sad speech, where the subjects were also educated speakers of Novi Sad background (МАрковић - БЈелАКовић 2009а: 142; СРедолевић 2009: 230-231; Средолевић - Суботић 2011: 122; SRedoJević 2013: 221-223; 2017: 147-148). 
of our participants, although the two words are distinguished by the posttonic length following the stressed syllable in the prescribed norm. The following words were analyzed:

1. cigarèta (cigarette, Nsg. f.), cigarétā (cigarette, Gpl. f.); 2. cüra ( girl, Nsg. f.), cûrāa (girl, Gpl. f.); 3. dëla (act, Gsg. n.), dêla (part, Gsg m. (deo)); 4. driblig (dribbling, Nsg. m.), Drína (prop. n., Nsg. f.); 5. gòra (wood, Nsg f.), górā (wood, Gpl. f.); 6. güma (tyre, Nsg. f.), gûmā (tyre, Gpl. f.); 7. käpa (hat, Nsg f.), kâpā (hat, Gpl. f.); 8. kapùtić (coat, Nsg. m. dim.), kapúti (coat, Npl. m.); 9. knjïga (book, Nsg. f.), knjîgā (book, Gpl. f.); 10. komàdić (piece, Nsg. m. dim.), komádi (piece, Npl. m.); 11. kôsa (blackbird, Gsg. m.), kösa (oblique, adj. indef. Nsg. f.); 12. Kósa (prop. n., Nsg. f.), kòsa (hair, Nsg. f.); 13. kòza (goat, Nsg. f.), kózā (goat, Gpl. f.); 14. kräva (cow, Nsg. f.), krâvā (cow, Gpl. f.); 15. küća (house, Nsg. f.), kûća (house, Gpl. f.); 16. kvadràtić (square, Nsg. m. dim.), kvadráti (square, Npl. m.); 17. papirić (paper, Nsg. m. dim.), papíri (paper, Npl. m.); 18. pùsti (let, imper. $2^{\text {nd }}$ p. sg.), pústi (desert, adj. Npl. m.); 19. räna (wound, Nsg. f.), rânā (wound, Gpl. f.); 20. sêna (hey, Gsg. n.), sëna (shadow, Nsg. f.); 21. sredina (environment, Nsg. f.), sredinā (environment, Gpl. f.); 22. vitlati (swirl, inf.), svitac (firefly, Nsg. m.); 23. vòda (water, Nsg. f.), vódā (water, Gpl. f.); 24. vrućina (heat, Nsg. f.), vrućínā (heat, Gpl. m.); 25. zàkloni (shelter, pres. $3^{\text {rd }}$ p. sg.), zákloni (shelter, Npl. m.); 26. žāba (frog, Nsg. f.), žâa $\bar{a}$ (frog, Gpl. f.); 27. žèna (woman, Nsg. f.), žénā (woman, Gpl. f.); 28. žǐca (wire, Nsg. f.), žîcā (wire, Gpl. f.).

None of the participants reported any speech or hearing disorders and they all took part in the study on a voluntary basis. The speakers were familiarized with the sentences prior to the recording session, in order to ensure natural pronunciation. The sentences were randomly ordered and presented to the speakers on a laptop screen, which was placed at their optimal distance. Each sentence was presented as a separate slide in PowerPoint to prevent the speakers from reading them as a list with typical rising intonation.

3.4. Measurements and anaLysis. For each target vowel we measured the first three formants (F1, F2, F3) in the medial (steady-state) portion of the vowel, avoiding consonant-to-vowel transitions, as recommended in the literature (HAYWARD 2000: 286). Most of the linguistic information on vowels is contained in F1 and F2 (as a function of vowel height and vowel backness respectively), while F3, as the most variable of the three formants, contains the information on lip rounding, but is also correlated with the overall fundamental frequency of the speaker and therefore carries more speaker-specific information. Although the values of F1 and F2 are considered as sufficient for assessing the quality of vowels, most researchers also include the values of $\mathrm{F} 3$ as representative of some relevant vocalic features.

The acoustic analysis was performed using Praat (version 6.1.09, BoERSMA - WeEnINK 2020). For the purpose of this study, we measured the frequencies of the first three formants, using the default Praat settings, adjusting them depending on the gender of the speakers analyzed, and increasing the number of formants for the high back vowels where necessary, to avoid F1 and F2 overlap.

Statistical analysis was performed by the Statistical Package for Social Sciences - SPSS 21. Numerical data are presented as mean values and standard deviations. For the comparison of formant values in short and long vowels, we used a two- 
tailed t-test for independent samples, where the statistical significance was taken to be at $\mathrm{p}<0.05$. The comparison was done within the long and short pairs with falling and rising accents separately, as well as on all long vs. short vowels regardless of the accent type. ${ }^{15}$ The same software was used for plotting F1-F2 graphs for each vowel in its short and long realization.

4. RESULTS. The results of our study will be presented for each vowel produced by women and men separately, providing the reader with the descriptive statistical data and vowel graphs based on all occurrences and mean values. The information given in tables includes the values of the first three formants for long (L) and short (S) vowels of both accent types (falling and rising), the number of instances measured $(\mathrm{N})$, mean formant values, standard deviations (SD), minimum and maximum values, $t$-test results and statistical significance $(\mathrm{p}<0.05)$. The results which are statistically significant are shown in bold type.

/i/

The results of the mean value measurements of F1, F2 and F3 of the high front vowel /i/ are:

Table 1: Data on F1, F2 and F3 of long and short /i/ produced by women.

\begin{tabular}{|c|c|c|c|c|c|c|c|c|}
\hline Parameter & Accent & $\mathrm{N}$ & Mean & SD & Min & Max & $\mathrm{t}$ test & $\mathrm{p}$ \\
\hline \multirow{2}{*}{$\mathrm{F} 1$} & $\mathrm{~L}$ & 56 & 352 & 53.13 & 246 & 470 & \multirow{2}{*}{ 1. 237} & \multirow{2}{*}{0.219} \\
\hline & $S$ & 56 & 364 & 48.78 & 278 & 487 & & \\
\hline \multirow{2}{*}{ F2 } & $\mathrm{L}$ & 56 & 2,656 & 123.08 & 2,315 & 2,870 & \multirow{2}{*}{2.680} & \multirow{2}{*}{0.008} \\
\hline & $\mathrm{S}$ & 56 & 2,587 & 148.76 & 2,148 & 3,059 & & \\
\hline \multirow{2}{*}{ F3 } & $\mathrm{L}$ & 54 & 3,244 & 253.4 & 2,721 & 3,955 & \multirow{2}{*}{3.830} & \multirow{2}{*}{0.000} \\
\hline & $\mathrm{S}$ & 54 & 3,066 & 226.41 & 2,652 & 3,570 & & \\
\hline
\end{tabular}

Table 2: Data on F1, F2 and F3 of long and short /i/ produced by men.

\begin{tabular}{|c|c|c|c|c|c|c|c|c|}
\hline Parameter & Accent & $\mathrm{N}$ & Mean & SD & Min & Max & $\mathrm{t}$ test & $\mathrm{p}$ \\
\hline \multirow{2}{*}{ F1 } & $\mathrm{L}$ & 56 & 314 & 40.93 & 236 & 434 & \multirow{2}{*}{1.759} & \multirow{2}{*}{0.081} \\
\hline & $\mathrm{S}$ & 56 & 328 & 42.27 & 248 & 421 & & \\
\hline \multirow{2}{*}{ F2 } & $\mathrm{L}$ & 56 & 2,164 & 182.25 & 1,837 & 2,532 & \multirow{2}{*}{2.259} & \multirow{2}{*}{0.026} \\
\hline & $\mathrm{S}$ & 56 & 2,085 & 187.45 & 1,757 & 2,609 & & \\
\hline \multirow{2}{*}{ F3 } & $\mathrm{L}$ & 56 & 2,718 & 229.82 & 2,312 & 3,433 & \multirow{2}{*}{2.976} & \multirow{2}{*}{0.004} \\
\hline & $\mathrm{S}$ & 54 & 2,597 & 193.76 & 2,235 & 3,132 & & \\
\hline
\end{tabular}

Although in the pronunciation of women the mean value of F1 is slightly lower in the long than in the short vowel $(352 \mathrm{~Hz}: 364 \mathrm{~Hz})$, this difference is not statistically significant. Produced by men, the mean value of F1 in the long vowel is also somewhat lower than in the short one $(314 \mathrm{~Hz}: 328 \mathrm{~Hz})$, but again with no statistical significance. On the whole, the height of the tongue in /i/ is obviously not significantly related to different vocalic quantities in our corpus. With both genders, the values F2 and F3 are significantly different in the pronunciation of

${ }^{15}$ Due to space limitations, we shall here only present the tables comparing all long and short occurrences (for both accent types) and not separately for falling and rising accent pairs. 
long and short /i/. The lower values of F2 in the short realization point to slight retraction of the tongue, i.e., slight centralization. Produced by women, the mean F2 value of the long vowel is $2656 \mathrm{~Hz}$, while in the short one it is $2587 \mathrm{~Hz}$. In the long /i/ produced by men, the mean F2 is $2164 \mathrm{~Hz}$, and in the short vowel it is $2085 \mathrm{~Hz}$. Although these differences are not high, they are consistently present and are statistically significant in both genders.

Based on these measurements, the plotted graphs of F1 and F2, shown in Figures 1 (women) and 2 (men), expectedly show general overlapping in the vowel space for the long and short realizations of $/ \mathrm{i} /$ in the pronunciation of both genders, with the mean values being very close to each other, except for slight retraction and insignificant lowering of the short allophone.

In all the graphs to be shown, symbol $\boldsymbol{\Delta}$ stands for the mean values of the long vowel, while $\square$ indicates the short one; grey-filled circles show all individual instances of long vowels, and white circles mark instances of short vowels.

Figure 1. Plotted F1-F2 graph of long /i/ and short /i/ - women.

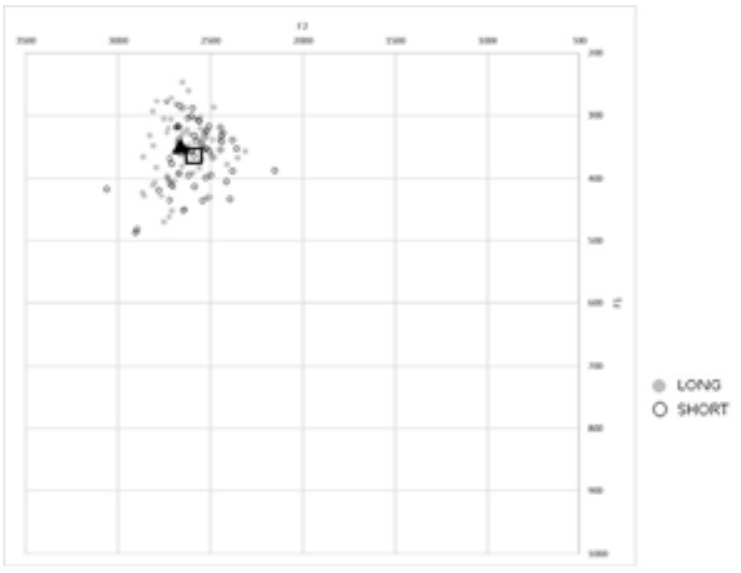

Figure 2. Plotted F1-F2 graph of long /i/ and short /i/ - men.

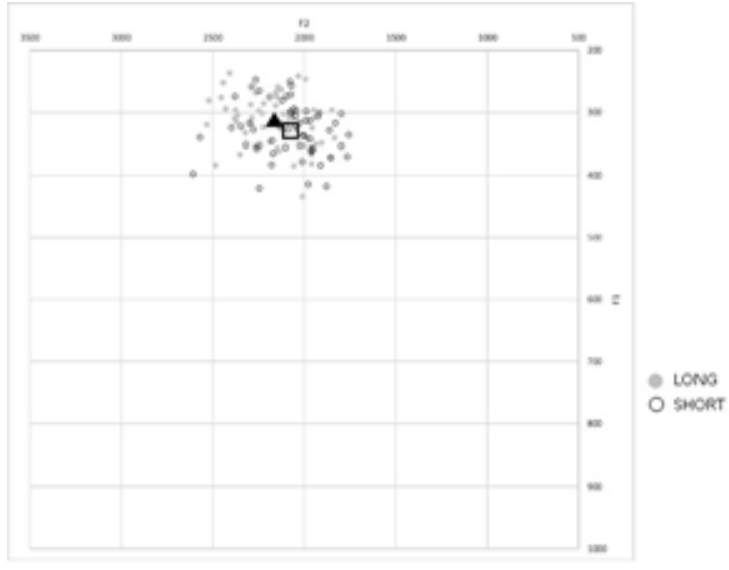


/e/

Tables 3 and 4 present the data about the first three formants of the long and short realizations of the vowel /e/

Table 3. Data on F1, F2 and F3 of long and short /e/ produced by women.

\begin{tabular}{|c|c|c|c|c|c|c|c|c|}
\hline Parameter & Accent & $\mathrm{N}$ & Mean & SD & Min & Max & $\mathrm{t}$ test & $\mathrm{p}$ \\
\hline \multirow{2}{*}{ F1 } & $\mathrm{L}$ & 40 & 523 & 59.77 & 428 & 656 & \multirow{2}{*}{12.286} & \multirow{2}{*}{0.000} \\
\hline & $\mathrm{S}$ & 39 & 728 & 89.44 & 585 & 911 & & \\
\hline \multirow{2}{*}{$\mathrm{F} 2$} & $\mathrm{~L}$ & 40 & 2,316 & 174.61 & 2,011 & 2,783 & \multirow{2}{*}{10.684} & \multirow{2}{*}{0.000} \\
\hline & $\mathrm{S}$ & 39 & 1,929 & 114.36 & 1,572 & 2,119 & & \\
\hline \multirow{2}{*}{ F3 } & $\mathrm{L}$ & 40 & 2,943 & 194.31 & 2,556 & 3,429 & \multirow{2}{*}{2.0570} & \multirow{2}{*}{0.043} \\
\hline & $\mathrm{S}$ & 38 & 2,839 & 233.82 & 2,364 & 3,443 & & \\
\hline
\end{tabular}

Table 4. Data on F1, F2 and F3 of long and short/e/ produced by men.

\begin{tabular}{|c|c|c|c|c|c|c|c|c|}
\hline Parameter & Accent & $\mathrm{N}$ & Mean & SD & Min & Max & $\mathrm{t}$ test & $\mathrm{p}$ \\
\hline \multirow{2}{*}{$\mathrm{F} 1$} & $\mathrm{~L}$ & 40 & 482 & 54.72 & 381 & 593 & \multirow{2}{*}{7.154} & \multirow{2}{*}{0.00} \\
\hline & $\mathrm{S}$ & 40 & 581 & 67.96 & 484 & 742 & & \\
\hline \multirow{2}{*}{$\mathrm{F} 2$} & $\mathrm{~L}$ & 40 & 1,902 & 128.88 & 1,679 & 2,254 & \multirow{2}{*}{10.722} & \multirow{2}{*}{0.000} \\
\hline & $\mathrm{S}$ & 40 & 1,604 & 119.60 & 1,405 & 1,866 & & \\
\hline \multirow{2}{*}{ F3 } & $\mathrm{L}$ & 40 & 2,496 & 123.87 & 2,190 & 2,763 & \multirow{2}{*}{2.571} & \multirow{2}{*}{0.012} \\
\hline & $\mathrm{S}$ & 40 & 2,419 & 143.53 & 2,037 & 2,673 & & \\
\hline
\end{tabular}

In line with previous findings, our analysis also reveals a remarkable difference between the long and short /e/ vowel in Novi Sad speech. Judging from the mean values and standard deviations, the difference is more striking in the pronunciation of women in terms of tongue height, i.e., in the openness of the short vowel. In women's pronunciation, the mean F1 value of the long vowel is $523 \mathrm{~Hz}$, while in the short one it is $728 \mathrm{~Hz}$, the difference being over $200 \mathrm{~Hz}$. In the pronunciation of men, F1 of the long vowel is $482 \mathrm{~Hz}$, and $581 \mathrm{~Hz}$ in the short realization. ${ }^{16}$ The values of F2 are considerably higher in the long than in the short vowel both in women's and in men's pronunciation (women: $2316 \mathrm{~Hz}$ : $1929 \mathrm{~Hz}$; men: $1902 \mathrm{~Hz}$ : $1603 \mathrm{~Hz}$ ). This retraction automatically accompanies the lowering of the tongue in the front area of vowel space, and shows the centralization effect in the short vowel. All three formants are significantly different in long and short /e/ in both genders.

The plotted F1-F2 graphs (Figures 3 and 4), as expected, show a total separation in the qualities of the long and short realizations of the vowels, indicated by the rather distant positions of the mean values in both genders' pronunciation. However, in the pronunciation of women (Figure 3), there is absolutely no overlapping in the areas of the long and short vowel, while in that of men, we do notice some overlapping. Indeed, during the analysis we noticed that some of the male speakers more or less consistently pronounced /e/ with a surprisingly small difference between

${ }^{16}$ It should be noted that the absolute formant values (measured in $\mathrm{Hz}$ ), without normalization, are not a reliable indicator of the difference between female and male speakers. 
the long and short allophone (male speaker no. 1 in particular, but speakers 3 and 4 also pronounced the two allophones with a smaller difference than the rest).

Figure 3. Plotted F1-F2 graph of long /e/ and short /e/ - women.

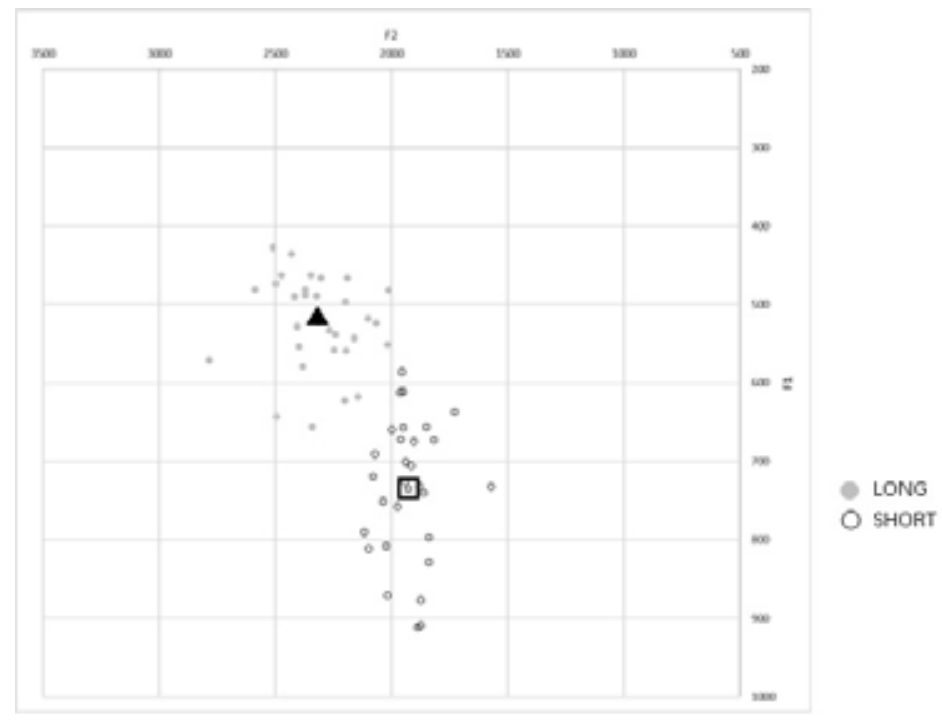

Figure 4. Plotted F1-F2 graph of long /e/ and short /e/ - men.

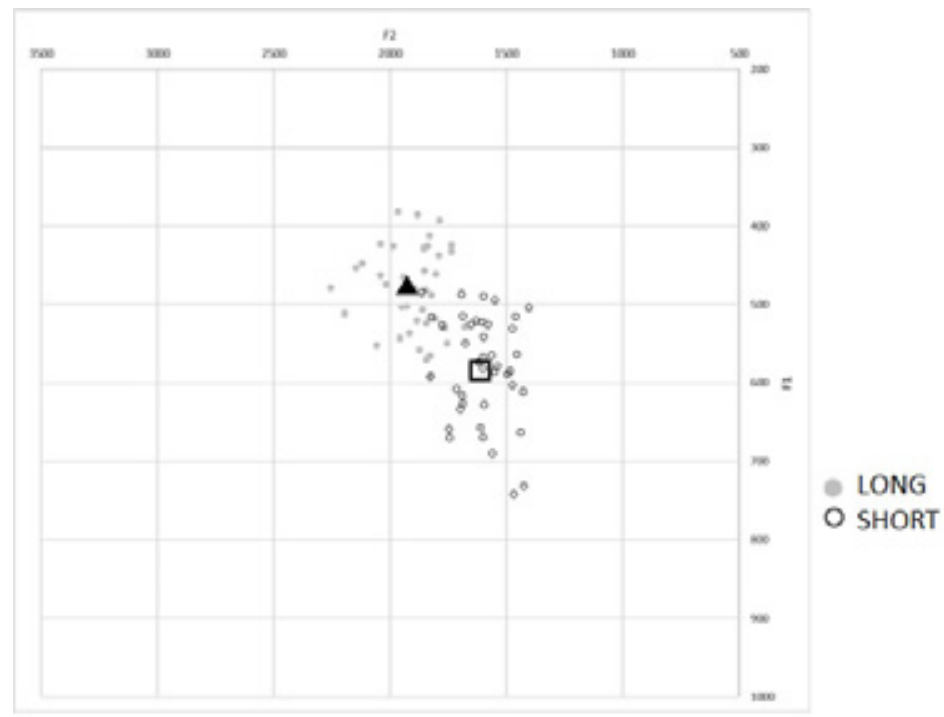

/a/

The results of formant values and statistical analysis between the long and short vowel /a/ are given in tables 5 (women) and 6 (men). 
Table 5. Data on F1, F2 and F3 of long and short /a/ produced by women.

\begin{tabular}{|c|c|c|c|c|c|c|c|c|}
\hline Parameter & Accent & $\mathrm{N}$ & Mean & SD & Min & Max & $t$ test & $\mathrm{p}$ \\
\hline \multirow{2}{*}{$\mathrm{F} 1$} & $\mathrm{~L}$ & 56 & 907 & 80.24 & 736 & 1,121 & \multirow{2}{*}{1.084} & \multirow{2}{*}{0.281} \\
\hline & $\mathrm{S}$ & 53 & 889 & 100.19 & 468 & 1,126 & & \\
\hline \multirow{2}{*}{ F2 } & $\mathrm{L}$ & 56 & 1,425 & 115.14 & 1,040 & 1,729 & \multirow{2}{*}{0.516} & \multirow{2}{*}{0.607} \\
\hline & $\mathrm{S}$ & 53 & 1,436 & 92.81 & 1,256 & 1,648 & & \\
\hline \multirow{2}{*}{ F3 } & $\mathrm{L}$ & 56 & 2,652 & 271.25 & 1,417 & 3,111 & \multirow{2}{*}{0.394} & \multirow{2}{*}{0.695} \\
\hline & $\mathrm{S}$ & 53 & 2,632 & 244.75 & 1,935 & 3,191 & & \\
\hline
\end{tabular}

Table 6. Data on F1, F2 and F3 of long and short/a/ produced by men.

\begin{tabular}{|c|c|c|c|c|c|c|c|c|}
\hline Parameter & Accent & $\mathrm{N}$ & Mean & SD & Min & Max & $t$ test & $\mathrm{p}$ \\
\hline \multirow{2}{*}{$\mathrm{F} 1$} & $\mathrm{~L}$ & 58 & 706 & 68.91 & 547 & 850 & \multirow{2}{*}{0.432} & \multirow{2}{*}{0.663} \\
\hline & $\mathrm{S}$ & 57 & 670 & 76.67 & 558 & 892 & & \\
\hline \multirow{2}{*}{$\mathrm{F} 2$} & $\mathrm{~L}$ & 58 & 1,230 & 82.24 & 1,032 & 1,415 & \multirow{2}{*}{0.628} & \multirow{2}{*}{0.531} \\
\hline & $\mathrm{S}$ & 57 & 1,241 & 103.39 & 1,041 & 1,472 & & \\
\hline \multirow{2}{*}{ F3 } & $\mathrm{L}$ & 58 & 2,365 & 317.87 & 1,844 & 2,881 & \multirow{2}{*}{1.413} & \multirow{2}{*}{0.159} \\
\hline & $\mathrm{S}$ & 57 & 2,318 & 153.61 & 1,997 & 2,667 & & \\
\hline
\end{tabular}

As can be seen from tables 5 and 6 , the long realization of /a/ is negligibly and insignificantly lower than the short one (mean F1 being $907 \mathrm{~Hz}$ in the long vowel, $889 \mathrm{~Hz}$ in the short one in women's pronunciation; $706 \mathrm{~Hz}$ in the long, $700 \mathrm{~Hz}$ in the short produced by men). There is no significant difference in the backness either, as F2 of both long and short vowel indicate a tendency towards the central position in the vowel space.

The plotted F1-F2 graphs of the vowel produced by both genders (Figures 5 and 6) show almost complete overlapping both of the mean values and of individual utterances of the short and long realizations of $/ a /$.

Figure 5. Plotted F1-F2 graph of long /a/ and short /a/ - women.

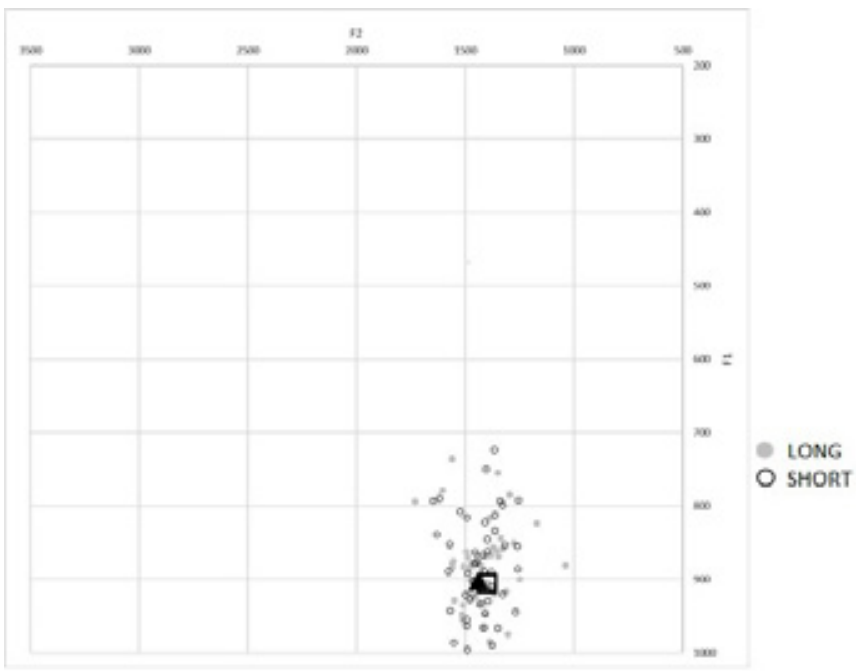


Figure 6. Plotted F1-F2 graph of long /a/ and short /a/ - men.

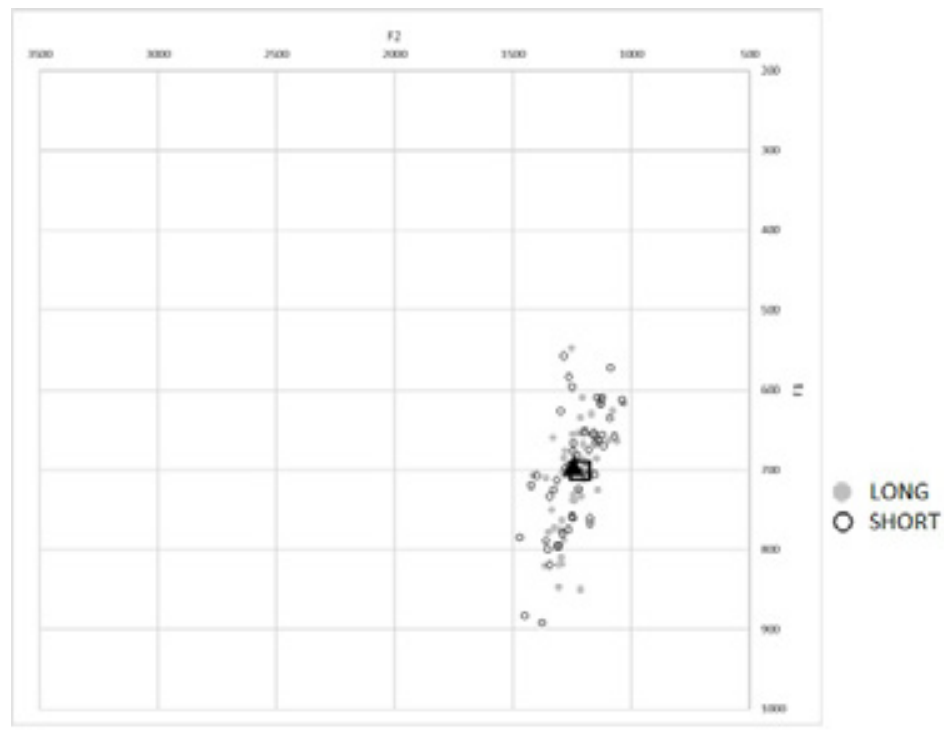

/o/

The data on the first three formants of long and short /o/ are presented in tables 7 and 8 in the pronunciation of both genders.

Table 7. Data on F1, F2 and F3 of long and short/o/ produced by women.

\begin{tabular}{|c|c|c|c|c|c|c|c|c|}
\hline Parameter & Accent & $\mathrm{N}$ & Mean & SD & Min & $\operatorname{Max}$ & $\mathrm{t}$ test & $\mathrm{p}$ \\
\hline \multirow{2}{*}{ F1 } & $\mathrm{L}$ & 50 & 491 & 38.93 & 396 & 596 & \multirow{2}{*}{12.575} & \multirow{2}{*}{0.000} \\
\hline & $\mathrm{S}$ & 50 & 622 & 62.22 & 430 & 730 & & \\
\hline \multirow{2}{*}{$\mathrm{F} 2$} & $\mathrm{~L}$ & 50 & 896 & 85.25 & 697 & 1,052 & \multirow{2}{*}{11.216} & \multirow{2}{*}{0.000} \\
\hline & $\mathrm{S}$ & 50 & 1,097 & 93.94 & 902 & 1,270 & & \\
\hline \multirow{2}{*}{ F3 } & $\mathrm{L}$ & 50 & 2,772 & 146.98 & 2,344 & 3,057 & \multirow{2}{*}{3.014} & \multirow{2}{*}{0.003} \\
\hline & S & 50 & 2,662 & 211.27 & 2,153 & 3,135 & & \\
\hline
\end{tabular}

Table 8. Data on F1, F2 and F3 of long and short/o/ produced by men.

\begin{tabular}{|c|c|c|c|c|c|c|c|c|}
\hline Parameter & Accent & $\mathrm{N}$ & Mean & SD & Min & Max & $\mathrm{t}$ test & $\mathrm{p}$ \\
\hline \multirow{2}{*}{$\mathrm{F} 1$} & $\mathrm{~L}$ & 50 & 467 & 41.73 & 401 & 623 & \multirow{2}{*}{7.104} & \multirow{2}{*}{0.000} \\
\hline & $\mathrm{S}$ & 49 & 528 & 43.47 & 449 & 626 & & \\
\hline \multirow{2}{*}{ F2 } & $\mathrm{L}$ & 50 & 833 & 61.82 & 695 & 926 & \multirow{2}{*}{10.488} & \multirow{2}{*}{0.000} \\
\hline & $\mathrm{S}$ & 49 & 959 & 58.18 & 836 & 1,084 & & \\
\hline \multirow{2}{*}{ F3 } & $\mathrm{L}$ & 50 & 2,428 & 106.75 & 2,159 & 2,704 & \multirow{2}{*}{2.216} & \multirow{2}{*}{0.029} \\
\hline & S & 49 & 2,376 & 126.52 & 2,110 & 2,674 & & \\
\hline
\end{tabular}


As in the previous studies on Novi Sad speech, our results also point to obviously significant differences between the long and short realizations of $/ \mathrm{o} /$ in the speech of our participants of both genders, comparative to those of the front mid vowel /e/. The difference is again more striking in tongue height in the speech of women, whose mean F1 in the long /o/ vowel is $491 \mathrm{~Hz}$, and $622 \mathrm{~Hz}$ in the short vowel, reflecting a much more open articulation of the short vowel. In men's pronunciation, the mean F1 of the long vowel is $467 \mathrm{~Hz}$, and $528 \mathrm{~Hz}$ in the short one. The second formant in both genders shows expected fronting (centralization) of the short vowel, mean F2 being $896 \mathrm{~Hz}$ in the long and $1097 \mathrm{~Hz}$ in the short realization in women, and $833 \mathrm{~Hz}$ in the long and $959 \mathrm{~Hz}$ in the short vowel in male speakers. All three formants (including F3) differ significantly between the long and short vowel.

The plotted F1-F2 graphs (Figures 7 - women, and 8 - men), show a rather clear separation of the two vocalic qualities depending on quantity, but unlike the front vowel /e/, there appears to be some overlapping even in the pronunciation of women, and much more so in men. Interestingly, the analysis of individual female speakers showed a less consistent pattern of changing the quality of the long and short /o/ sound, despite the unquestionable overall tendency. Again, more male speakers failed to change the quality of the long and short vowel significantly and consistently throughout the corpus.

Figure 7. Plotted F1-F2 graph of long /o/ and short /o/ - women.

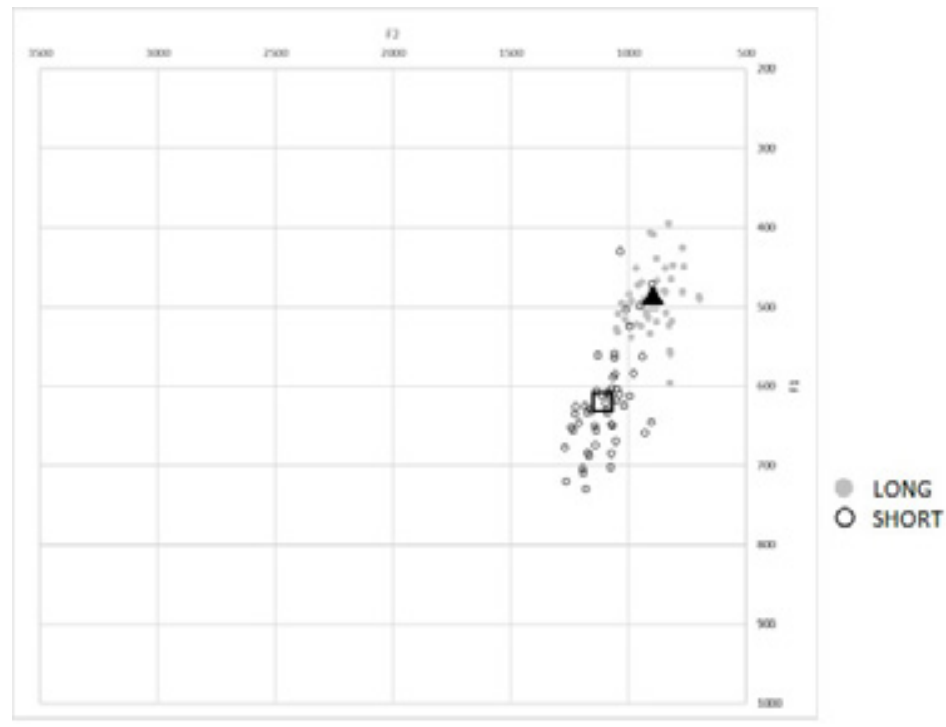


Figure 8. Plotted F1-F2 graph of long /o/ and short /o/ - men.

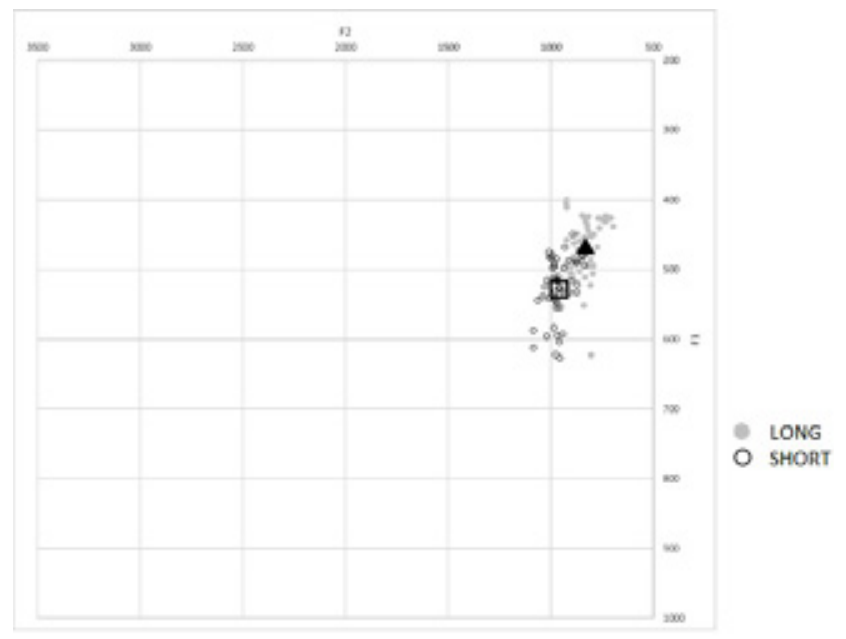

$/ \mathrm{u} /$

The data on F1, F2 and F3 of the long and short realizations of high back vowel /u/ are given in tables 9 (women) and 10 (men).

Table 9. Data on F1, F2 and F3 of long and short /u/ produced by women.

\begin{tabular}{|c|c|c|c|c|c|c|c|c|}
\hline Parameter & Accent & $\mathrm{N}$ & Mean & SD & Min & Max & $\mathrm{t}$ test & $\mathrm{p}$ \\
\hline \multirow{2}{*}{ F1 } & $\mathrm{L}$ & 45 & 369 & 47.38 & 271 & 499 & \multirow{2}{*}{1.669} & \multirow{2}{*}{0.09} \\
\hline & $\mathrm{S}$ & 45 & 386 & 46.90 & 286 & 505 & & \\
\hline \multirow{2}{*}{ F2 } & $\mathrm{L}$ & 45 & 737 & 109.84 & 540 & 1,015 & \multirow{2}{*}{4.671} & \multirow{2}{*}{0.000} \\
\hline & $\mathrm{S}$ & 45 & 864 & 144.21 & 608 & 1,193 & & \\
\hline \multirow{2}{*}{ F3 } & $\mathrm{L}$ & 45 & 2,721 & 204.1 & 2,263 & 3,087 & \multirow{2}{*}{0.350} & \multirow{2}{*}{0.727} \\
\hline & $\mathrm{S}$ & 45 & 2,706 & 217.72 & 2,235 & 3,327 & & \\
\hline
\end{tabular}

Table 10. Data on F1, F2 and F3 of long and short/u/ produced by men.

\begin{tabular}{|c|c|c|c|c|c|c|c|c|}
\hline Parameter & Accent & $\mathrm{N}$ & Mean & SD & Min & Max & $\mathrm{t}$ test & $\mathrm{p}$ \\
\hline \multirow{2}{*}{ F1 } & $\mathrm{L}$ & 45 & 346 & 46.81 & 265 & 485 & \multirow{2}{*}{0.084} & \multirow{2}{*}{0.933} \\
\hline & $\mathrm{S}$ & 45 & 347 & 44.09 & 289 & 499 & & \\
\hline \multirow{2}{*}{$\mathrm{F} 2$} & $\mathrm{~L}$ & 45 & 716 & 78.85 & 603 & 927 & \multirow{2}{*}{4.528} & \multirow{2}{*}{0.000} \\
\hline & $\mathrm{S}$ & 45 & 798 & 92.19 & 629 & 1,027 & & \\
\hline \multirow{2}{*}{ F3 } & $\mathrm{L}$ & 45 & 2,297 & 214.38 & 1,614 & 2,818 & \multirow{2}{*}{0.063} & \multirow{2}{*}{0.950} \\
\hline & $\mathrm{S}$ & 45 & 2,299 & 160.43 & 2,036 & 2,698 & & \\
\hline
\end{tabular}

The data in tables 9 and 10 show that the main quality difference between the long and short realizations of the high back vowel /u/ is achieved by slight fronting (centralization) of the short allophone, indicated by the statistically significant differences in F2 values $(737 \mathrm{~Hz}: 864 \mathrm{~Hz}$ in women, $716 \mathrm{~Hz}: 798 \mathrm{~Hz}$ in men). The first formant is not a significant distinguisher between the long and 
short vowel, despite the lower mean value in the pronunciation of women. Unlike the front high vowel /i/, F3 in /u/ does not significantly correlate with quantity.

The plotted F1-F2 graphs of long and short /u/ are given in Figures 9 (women) and 10 (men). Most long and short realizations share much of the area in the vowel space, although the images also reveal the tendency to fronting in the short vowel.

Figure 9. Plotted F1-F2 graph of long /u/ and short /u/ - women.

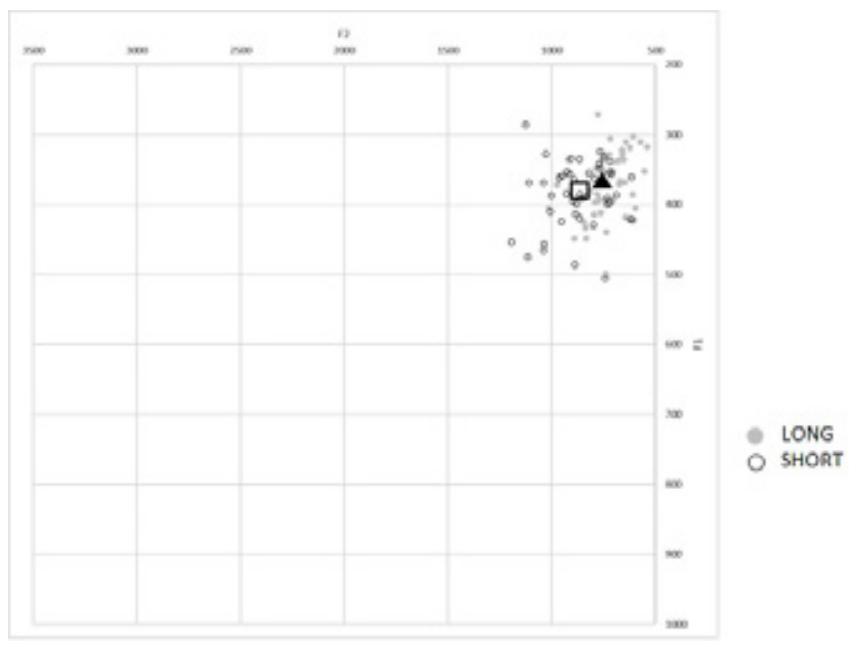

Figure 10. Plotted F1-F2 graph of long /u/ and short /u/ - men.

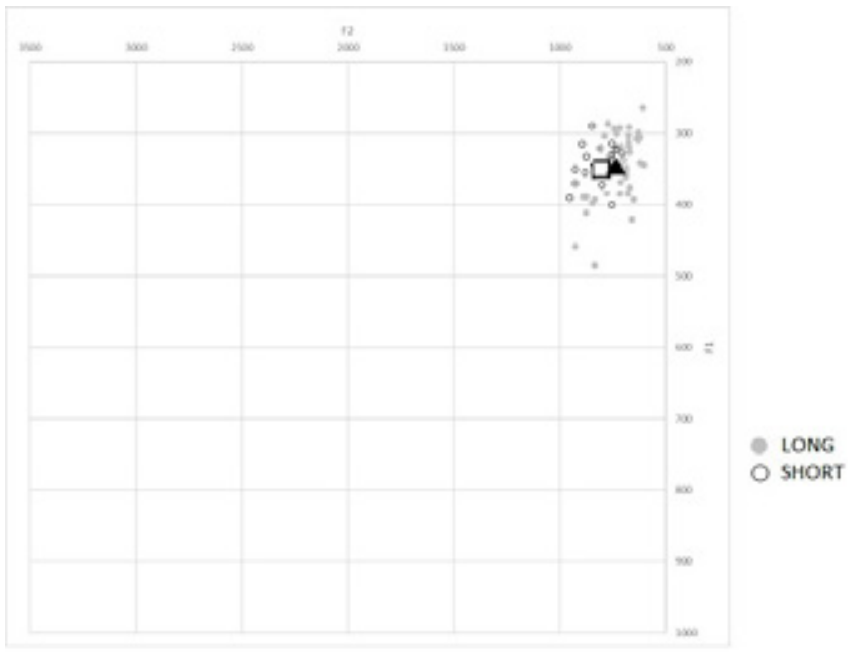

5. Discussion. Comparing the results of our research with those of previous studies on the spectral quality of vowels in Standard Serbian shows a pattern earlier described in this language, but is also indicative of some specific features, probably typical of Novi Sad speech, which may even be distinct in this way from 
other Vojvodinian dialects and an earlier pattern observed by Ivić and Lehiste (IVIĆ - LeHISTE 1963; 1967).

As expected, the results obtained here are the most similar to those found in Marković - BJelaković 2006; 2008a; Marković 2012, since all three studies examined the spectral qualities of vowels with all four accents of Standard Serbian, and the participants in all of them were citizens of Novi Sad. Except for minor differences in the formant values reported in the previous and present study, resulting from the different choice of speakers and a general huge inter-speaker variability, the pattern we observed here is highly consistent with that found in Marković - BJelaković 2006; 2008 and Marković 2012.

The most conspicuous difference between our study and Ivić - LeHISTE 1963 and Ivić - LEHISTE 1967 is the differentiation in the quality of vowel /a/ as a result of quantity difference that these authors reported. While the earlier research found significant difference between the long and short vowel in the pronunciation of Ivić, our results do not corroborate this finding. The reason for this difference may be in the fact that Ivić, who was born in Belgrade in 1924, spent his early life living in Subotica (until 1941), then lived in Belgrade until 1955, and then in Novi Sad (IviĆ - LeHISTE 1963: 35). Taking into consideration that marked regional accents were not as typical of educated language specialists at that time as may be the case today, it is plausible to assume that Ivić's pronunciation did not completely reflect the state of this urban variety as we know it today. In addition to this, more than half a century later, we may expect vowels of any language to show considerable change in comparison to an earlier period, so our findings may be indicative of such a change.

Compared with the results of other studies on vowels in Serbian and Croatian, ours obviously point to a clear-cut quality distinction between the long and short mid vowels /e/ and /o/, which were reported in the past (but also refuted in some studies and for some dialects), ${ }^{17}$ but mostly not with such marked differences between the two sets of allophones as in our study.

Except for these two vowels, the other vowels examined clearly show that Standard Serbian described in this research may be qualified as a 'quantity' language, where the minor differences in the long and short vowels $/ \mathrm{i}, \mathrm{u}, \mathrm{a} /$ are just concomitant phonetic features resulting from insufficient time to reach 'target' positions in the vocal tract.

What we noticed during our research, but did not have resources to investigate deeper due to the specific methodology involved, is an inter-speaker variation in the pattern of quality and quantity relation. Some speakers seemed to be much more consistent in their differentiation of the quality of long and short vowels, while others were less so. Even more surprising was the indication that the difference in the quality of long and short /e/ and /o/ might be, to an extent, gender related, which may point to certain sociolinguistic factors that have not been studied in Serbian phonology. This may be illustrated by the diagrams of long and short vowels based on the mean F1 and F2 values obtained in our study, presented in Figures 11.a (women) and 11.b (men):

\footnotetext{
${ }^{17}$ Compare the results for Serbian and Croatian in Section 2.
} 
Figure 11.a Vowel diagram - women

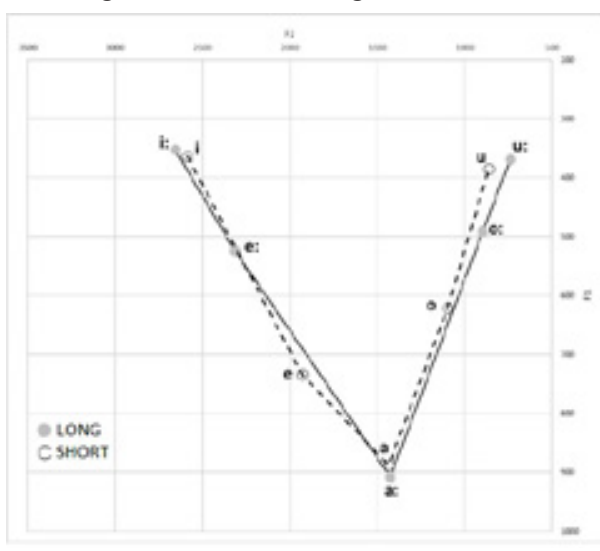

Figure 11.b Vowel diagram - men

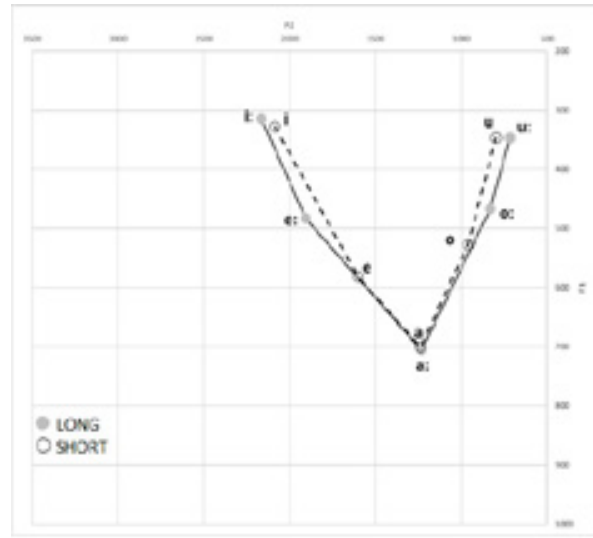

Although the two diagrams undoubtedly exhibit a similar pattern, it appears that the mid-high /e/ and /o/ are more dispersed in women's pronunciation, so that long /e/ is more distant from its short equivalent than from the high vowel /i/, and long $/ \mathrm{o} /$ is rather close to the area of $/ \mathrm{u} /$. Articulated by men, the long and short allophones seem to be somewhat closer to each other, as was also obvious from the individual vowel diagrams presented in the previous section, where there was much more overlap for the short and long vowel in men's production than in women's.

6. Conclusions. Our study of the relationship between vocalic quantity and quality in the Standard Serbian variant spoken by educated speakers from Novi Sad was based on the articulation and did not include any investigation into the perception of quality/quantity distinctions. With this in mind, we may predict that quality would be the most likely overriding factor for the perception of long vs. short /e/ and /o/, but would probably fail to be the decisive cue for the perception of other vowels. However, duration alone may not be the only temporary distinction between the long and short realizations of vowels, since other phonetic characteristics, such as the F0 curve, peak, range, intensity measures, etc., are also differently arranged in long and short vowels (for Novi Sad speech, see Sredojević 2017: 60-62, 68-70; SREDoJević - MARKović 2020: 45-48). It is appealing to a phonologist to attribute a single phonetic feature to a phonological contrast (such as duration, for example, distinguishing between phonologically long and short vowels), but before perception experiments on the phenomenon of quantity/quality interrelationship in Serbian are conducted, such predictions remain in the realm of speculation. We believe that future studies on perception of the phenomenon discussed in this paper would certainly yield precious new information and would give linguists the opportunity to come to a much deeper understanding of quantity vs. quality distinctions in vowels. In addition to perception experiments, research into the relationship between vowels in clear and conversational speech might also shed additional light on the effect of quantity on quality.

It goes without saying that the results presented here are representative of one single variety of Standard Serbian, spoken in the second largest city in Serbia. 
Without any ambition to extend our findings to the other varieties or dialects of the Serbian language, we are hoping to encourage future research projects which would in a similar way, or in more detail, describe the sounds of other Serbian dialects, and thus provide a valuable description of the state-of-the-art situation that might serve various purposes - from applied sciences, such as speech technologies, forensic studies, language teaching, audiological research, etc., to the more theoretical ones, such as the description of the contemporary standard(s), sociolinguistic studies, and even the diachronic research of language change.

\section{REFERENCES}

Abramson, Arthur S., Nianqi Ren. Distinctive Vowel Length: Duration vs. Spectrum in Thai. Journal of Phonetics 18/2 (1990): 79-92.

BAKRAN, Juraj. Djelovanje naglaska i dužine na frekvencije formanata vokala. Govor VI/2 (1990): 1-12.

BAšić, Iva. Akustička analiza općeprihvaćenoga hrvatskoga i srpskog govora-formantska analiza i mjere fundamentalne frekvencije. Zagreb: Filozofski fakultet Sveučilišta u Zagrebu, 2018. [PhD Thesis].

Behne, Dawn, Bente Moxness, Anne Nyland. Acoustic-Phonetic Evidence of Vowel Quantity and Quality in Norwegian. Speech, Music and Hearing, Quarterly Progress and Status Report (TMH-QPSR) 37/2 (1996): 13-16.

Behne, Dawn, Peter E. Czigler, Kirk P. H. Sullivan. Swedish Quantity and Quality: A Traditional Issue Revisited. Reports fron the Department of Phonetics, Umea University 4 (1997): 81-83.

Boersma, Paul, David Weenink. Praat: Doing Phonetics by Computer (Version 6.1.09) [Computer Program] $<$ http://www.praat.org $><26^{\text {th }}$ January $2020>$.

CATford, John Cunnison. Fundamental Problems in Phonetics. Edinburgh: University Press, 1977.

Hayward, Katrina. Experimental Phonetics. Harlow: Pearson Education Limited, 2000.

Ivić, Pavle, Ilse Lehiste. Prilozi ispitivanju fonetske i fonološke prirode akcenata u savremenom srpskohrvatskom književnom jeziku. Зборник за филолойију и линївистиику VI (1963): 31-73.

Ivić, Pavle, Ilse Lehiste. Prilozi ispitivanju fonetske i fonološke prirode akcenata u savremenom srpskohrvatskom jeziku. Зборник за филолойију и линівисииику X (1967): 55-95.

KAšić, Zorka. Govor Konavala. Срйски gијалекӣолощики зборник XLI (1995): 241-396.

LeHISTE, Ilse. Suprasegmentals. Cambridge: MIT Press, 1970.

LindBlom, Björn. Spectrographic Study of Vowel Reduction. Journal of the Acoustical Society of America 35 (1963): 1773-1781.

Maddieson, Ian. Patterns of Sounds. Cambridge University Press, 1984.

MARKović, Maja. Uporedna proučavanja vokala engleskog $i$ srpskog jezika: između univerzalnog $i$ specifičnog. Novi Sad: Filozofski fakultet, Odsek za anglistiku, 2012.

Marković, Maja, Isidora BJElAKović. Neke akustičke karakteristike vokala u govoru Novog Sada. Годищњ ак Филозофскоі факулиеетиа у Новом Саgу XXXI (2006): 327-346.

Marković, Maja, Isidora BJelaković. Kontrastivna akustička analiza vokalskih sistema srpskog i hrvatskog jezika. Branko Tošović (ur.). Die Unterschiede zwischen dem Bosnischen/Bosniakischen, Kroatischen und Serbischen, 2008a, 200-215.

MARKović, Maja, Isidora BJELAKović. Kvantitativno-kvalitativni odnosi akcentovanih vokala u govoru Novog Sada. Zbornik radova DOGS 2008, 2008b, 75-79.

PAunović, Tatjana. Fonetsko-fonološka interferencija srpskog jezika u percepciji i produkciji engleskih vokala. Niš: Filozofski fakultet, 2002. [PhD Thesis].

Peterson, E. Gordon, Ilse Lehiste. Duration of Syllable Nuclei in English. Journal of the Acoustical Society of America 32/6 (1960): 693-703.

PletiKos, Elenmari. Akustički opis hrvatskih standardnih naglasaka. Govor XX/1-2 (2003): 321-345.

Punišić, S, I. SAwicka. Fonetyka/Fonologia. Opole: Uniwersytet Opolski - Instytut Filologii Polskiej, $2007,557-576$.

SoviLJ-Nikić, Sandra. Trajanje vokala kao jedan od prozodijskih elemenata u sintezi govora na srpskom jeziku. Novi Sad: Fakultet tehničkih nauka, 2007. [MA Thesis].

SovilJ-Nikić, Sandra, Ivan SoviLj-Nikić, Maja Marković. Meta Learning Approach to Phone Duration Modeling. Tehnički vjesnik 25/3(2018): 855-860. 
SRedojević, Dejan. Neakcentovane dužine i jezik medija. Vesna Krčmar (ur.). Zbornik radova Akademije umetnosti 1 (2013): 205-224.

SREDoJević, Dejan. Fonetsko-fonološki opis akcenata u standardnom srpskom jeziku-od specifičnog ka opštem. Novi Sad: Filozofski fakultet, 2017.

Sredojević, Dejan, Maja Marković. Qualitative and Quantitative Distinctions Between Lexical Accents of Standard Serbian in the Speech of Novi Sad (Minimal Pair Corpus). Зборник Майиие срйске за филолойју и линіивсииику LXIII/2 (2020): 33-53.

Subotić, Ljiljana, Dejan Sredojević, Isidora BJElaković. Fonetika i fonologija: ortoepska i ortografska norma standardnog srpskog jezika [Elektronski izvor]. Novi Sad: Filozofski fakultet, 2012.

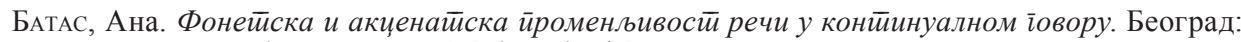
Филолошки факултет, 2014. [PhD Thesis].

БЕлит, Александар. Дијалекйи истиочне и јужне Србије. Београд: Завод за уџбенике и наставна средства, 1999.

БолАнит, Михаило, Растислава Тривунац. Рјечник дубровачког говора. Срйски gијалекӣолощки зборник XLIX (2002): 1-458.

Букумирић, Милета. Говори северне Метохије. Срйски дијалекитолощки зборник L (2003): 1-356.

Ивић, Павле. Белешке о биограчићком говору. Срйски gијалекіиолощики зборник XXIV (1978): $125-176$.

Ивић, Павле, Жарко БошњАковић, Гордана ДрАгин. Банатски говори шумадијско-војвођанског дијалекта. Књ. 1, Увод и фонетизам. Срииски gијалекиеолощки зборник XL (1994): 1-419.

Ивић, Павле, Илсе ЛЕхисте. Прозоgија речи и реченице у срйскохрвайском језику. Сремски Карловци - Нови Сад: Издавачка књижарница Зорана Стојановића, 1996.

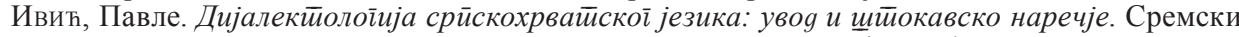
Карловци - Нови Сад: Издавачка књижарница Зорана Стојановића, 2001.

Јовић, Душан. Трстенички говор. Срйски яијалекеиолощки зборник XVII (1968): 1-240.

ЛАкчевић, Снежана, Љиљана ЂорЂевић, Гордана Жикић, Нада ДЕлић, Верица Ристић, Гордана Недељковић, Драган Вукмировић, Миливоје Грьовић. Сйановнищитво. Школска сйре-

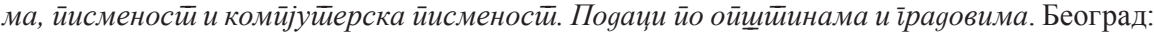
Републички завод за статистику Србије, 2013.

ЛАкчввић, Снежана, Љиљана ЂорЂевић, Гордана Жикић, Нада Делић, Верица Ристић, Гордана НЕдЕљковић, Драган Вукмировић, Миливоје Грьовић. Сйановнищйво. Уӣореgни йреїлеg броја стиановника 1948, 1953, 1961, 1971, 1981, 1991, 2002. и 2011. Подации йо насељима. Београд: Републички завод за статистику Србије, 2014.

МАрковић, Маја. Теорија дисперзије и вокалски систем српског језика. Зборник Майице срйске за филолоїију и линівистиику LV/2 (2012) 53-70.

МАРковић, Маја, Исидора БЈелАКовић. Квантитет дугих посттоничних вокала у говору Новог Сада. Жарко Бошњаковић (ур.). Говор Нової Саgа. Св. 1, Фонейске особине. Нови Сад: Филозофски факултет, Одсек за српски језик и лингвистику, 2009a, 141-147.

МАрковић, Маја, Исидора БЈелАковић. Квантитет наглашених вокала у говору Новог Сада. Жарко Бошњаковић (ур.). Говор Нової Саgа. Св. 1, Фонейске особине. Нови Сад: Филозофски факултет, Одсек за српски језик и лингвистику, 2009б, 148-158.

Милетић, Бранко. Изговор српскохрватских гласова (експериментално-фонетска студија). Срйски яијалекииолощки зборник V (1933): 1-161.

Николић, Берислав. Сремски говор. Срйски gијалекӣолощики зборник XIV (1964): 202-412.

Петровић, Драгољуб, Снежана Гудурић. Фонолойија срӣкойа језика. Београд - Нови Сад: САНУ, Институт за српски језик - Београдска књига - Матица српска, 2010.

Пецо, Асим, Бранислав МилАновић. Ресавски говор. Срйски gијалекӣолощки зборник XVII (1968): 241-366.

Поповић, Иван. Говор Госйођинаиа у свейлосиии бачких йовора као иелине. Посебна издања, књига CDXXV, Одељење литературе и језика, књига 21. Београд: САНУ, 1968.

РАдић, Првослав. Цртице о селу говора Мрче у куршумлијском крају. Срииски gијалекӣолощки зборник XXXVI (1990): 1-74.

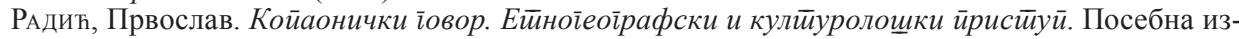
дања, књига 70. Београд: САНУ - Етнографски институт, 2010.

Реметић, Слободан. Говори централне Шумадије. Срйски яијалекиетолощки зборник XXXI (1985): $1-555$. 
PMC: Речник срӣскохрвайскоїа књижевної језика, I-III. Нови Сад - Загреб: Матица српска - Матица хрватска, 1967-1969; IV-VI, Нови Сад: Матица српска, 1967-1976. [коришћено фототипско издање из 1982. године].

Соколовић, Мирјана. Утицај акцената на формантску структуру вокала. Срйски језик II/1-2 (1997): 65-85.

СРедолевић, Дејан. Акценат именица у језику водитеља-спикера новосадских телевизијских станица. Жарко Бошњаковић (ур.). Говор Нової Саgа. Св. 1, Фонейске особине. Нови Сад: Филозофски факултет, Одсек за српски језик и лингвистику, 2009, 215-234.

Средолевић, Дејан, Љиљана СуБотић. Дугоузлазни акценат у новосадском говору: фонетске карактеристике и фонолошка интерпретација. Зборник Майице срйске за филолойију и линївисииику LIV/2 (2011): 108-133.

ТомА, Пол-Луј. Говори Ниша и околних села [са француског превео Сава Анђелковић]. Срйски gијалекӣолощки зборник XLV (1998).

Шпис, Марија. Фонолошки опис говора Парага. Срйски яијалекйолощки зборник XXXVII (1991): 549-621.

Маја Марковић

Дејан Средојевић

\title{
СПЕКТРАЛНЕ КАРАКТЕРИСТИКЕ НАГЛАШЕНИХ ВОКАЛА СТАНДАРДНОГ СРПСКОГ ЈЕЗИКА: ОДНОС КВАНТИТЕТА И КВАЛИТЕТА
}

\author{
Рези и е
}

У раду су представљени резултати анализе спектралних карактеристика наглашених вокала под дугим и кратким акцентом у стандардном српском језику новосадског варијетета, добијени у оквиру опсежније експерименталне студије прозодијских и квалитативних карактеристика вокала. Истраживање је спроведено на до сада највећем корпусу минималних парова речи с дугим и кратким акцентима истог квалитета, које су се налазиле у средишњем положају краћих реченица. На основу снимака 10 говорница и 10 говорника, махом универзитетских наставника, анализирано је 56 вокала у укупо 1120 примера. Циљ истраживања био је да се опишу типичне разлике у квалитету дугих и кратких наглашених вокала у овом урбаном варијетету и да се досадашња истраживања допуне подацима заснованим на минуциозној статистичкој анализи података из пажљиво бираног корпуса. Такође, желели смо да установимо да ли су варијације у квалитету доследне или су, евентуално, идиосинкратичне, као и да ли постоји разлика између изговора мушкараца и жена. С обзиром на то да су резултати поређени с резултатима претходних истраживача, занимало нас је и да ли постоје евентуалне разлике у односу на ранија истраживања. Резултати потврђују да се највеће разлике у квалитету јављају код вокала /e/ и /o/ под дугим, односно кратким акцентом, али се показују и статистички значајне разлике између осталих дугих и кратких вокала у изговору већине снимљених говорника. Занимљиво је да су разлике између дуге и кратке реализације вокала /e/ и /o/ знатно израженије код жена него код мушкараца, што може да указује на одређену социолингвистичку дистинкцију.

Maja Marković

University of Novi Sad

Faculty of Philosophy

Department of English Studies

Dr Zorana Đinđića 2, 21000 Novi Sad, Serbia

majamarkovic@ff.uns.ac.rs

Dejan Sredojević

University of Novi Sad

Faculty of Philosophy

Department of Serbian Language and Linguistics

Dr Zorana Đinđića 2, 21000 Novi Sad, Serbia

dsredojevic@ff.uns.ac.rs
(Примљено: 28. августа 2021; прихваћено: 28. октобра 2021) 